Original Research Article

\title{
Correlation of coronary artery atherosclerosis typing and luminal narrowing with ischemic myocardial lesions in post mortem heart specimens: a four year retrospective study
}

\author{
Singh P. ${ }^{1}$, Satarkar R.N. ${ }^{2}$, Kalhan S. ${ }^{3}$, Hasija S. ${ }^{4}$, Bhawna $^{5}$, Sangwaiya A. ${ }^{6}$, Chawla S. ${ }^{7}$ \\ ${ }^{1}$ Dr. Pawan Singh, Associate Professor, ${ }^{2}$ Dr. Rahul N. Satarkar, Associate Professor, ${ }^{3}$ Dr. Shivani Kalhan, Professor, \\ ${ }^{4}$ Dr. Sonia Hasija, Assistant Professor, ${ }^{5}$ Dr. Bhawna, Associate Professor, ${ }^{6}$ Dr. Ashok Sangwaiya, Assistant Professor; \\ above all authors affiliated with Department of Pathology, SHKM Govt Medical College, Nalhar, Nuh, Haryana, India, \\ ${ }^{7}$ Dr. Suraj Chawla, Assistant Professor, Department of Community Medicine, SHKM Govt Medical College, Nalhar, \\ Nuh, Haryana, India.
}

Corresponding Author: Dr. Rahul N Satarkar, Associate Professor, Department of Pathology, SHKM Govt Medical College, Nalhar, Nuh, Haryana, India, Email: rsatarkar@gmail.com

\begin{abstract}
Introduction: Atherosclerosis accounts for a large proportion of cardiovascular system associated morbidity and mortality. Coronary artery disease (CAD) is the leading cause of global deaths with about $80 \%$ of burden occurring in developing countries. Material \& Methods: In order to assess the magnitude of the problem, a retrospective study of autopsy cases for the presence of atherosclerotic lesions of coronary arteries and associated ischemic cardiac lesionswas under taken from January 2013 to December 2017. Also, correlation of the atherosclerosis with ischemic heart diseases was studied. Result: Total number of heart specimens received in department of Pathology during four years were 272. Out of these 57 were autolyzed and were excluded from the study. Significant atherosclerotic lesions were seen in $54(25.11 \%)$ and $64(29.76 \%)$ cases in right and left coronary arteries respectively and were statistically significantly higher among age group $>41$ years as compared to those with age $<41$ years, overall atherosclerotic lesions were significantly higher in age groups $>41$ years as compared to $<41$ years. Conclusion: Maximum number of significant cardiac lesion were associated with atherosclerotic type VIII lesions (75\%) followed by type VII (66.66\%) and type VI (33.33\%). Maximum number of significant myocardial lesions were associated with grade IV (66.66\%) coronary luminal narrowing followed by grade III (45.71) and grade II (38.46). The study also showed significant correlation between the higher grade of the coronary atherosclerotic lesions and the ischemic heart disease.
\end{abstract}

Key words: Atherosclerosis, Autopsy, Coronary artery, Heart, Ischemic Heart Disease, Postmortem

\section{Introduction}

In India, CAD has emerged as the single largest disease accounting for nearly one third of all deaths. The incidence of coronary artery disease has doubled during past three to four decades. A total of nearly 6.4 crore cases of coronary artery disease were likely to occur in the year 2015; nearly $96 \%$ would be coronary heart disease cases [1]. An estimated 1.3 million Indian died from this in 2000. The projected deaths from coronary artery disease by 2015 were 2.95 million, of which $14 \%$ will be under 30 years and $31 \%$ will be under 40 years [2]. CAD is the leading cause of global deaths with about $80 \%$ of burden occurring in developing countries $[3,4]$. There is an alarming increase in the morbidity and

Manuscript received: $6^{\text {th }}$ May 2018

Reviewed: $16^{\text {th }}$ May 2018

Author Corrected: $24^{\text {th }}$ May 2018

Accepted for Publication: $28^{\text {th }}$ May 2018 mortality due to coronary atherosclerosis in India. There is no valid method for sampling of living population. The exact global incidence of atherosclerosis is not possible to calculate because it can exist without producing any signs \& symptoms. The autopsy study provides a means of understanding the basic process which sets a stage for clinically significant atherosclerotic cardiovascular disease [1].

In order to assess the magnitude of the problem, a retrospective study of autopsy cases for the presence of atherosclerotic lesions of coronary arteries and associated ischemic cardiac lesions like acute myocardial infarction (MI) /chronic ischemic heart disease (CIHD)/myocardial fibrosis (MF) / left ventricular hypertrophy $(\mathrm{LVH})$ was under taken for a 


\section{Original Research Article}

period of 4 year from January 2013 to December 2017. Also, correlation of the atherosclerosis with ischemic heart diseases was studied in a tertiary care institute established in rural and backward region.

\section{Material and Methods}

Place and type of study: This study was conducted retrospectively in Department of Pathology of SHKM Govt. Medical College, Nalhar from January 2014 to December 2017 (4 years).

Sampling method, collection and inclusion criteria: Total 272 postmortem heart specimens, irrespective of cause of death (natural, unnatural or sudden death) were received in Dept. of Pathology of SHKM Govt. Medical College, Nalhar, during January 2014 to December 2017. Specimens of the whole heart irrespective of the age and sex were reviewed and included in the study and fresh sections were taken wherever required.

Exclusion criteria: Autolysed specimens were excluded from study.

Micro sections from representative areas of heart were examined for the presence \& extent of coronary atherosclerosis and evidence of acute myocardial infarction / myocardial fibrosis / left ventricular hypertrophy. Detailed medical history and clinical diagnosis before death in review of the cases were not available.

Typing of atherosclerotic plaque was done as per the criteria of American Heart Association [5, 6].
Type I: Isolated intimal foamy cell (minimal change)

Type II: Numerous intimal foamy cells often in layers (fatty streaks)

Type III: Pools of extracellular lipids without a welldefined core (intermediate lesion or preatheroma)

Type IV: Well defined lipid core with luminal surface covered by normal intima (atheroma or fibroplaque)

Type V: Lipid core with a fibrous cap with or without calcification (fibroatheroma)

Type VI: Fibroatheroma with cap defect such as haemorrhage or thrombosis

Type VII: Calcification prominent

Type VIII: Fibrous tissue change prominent

The stenosis of coronaries was graded based on the luminal narrowing of the coronaries and is graded from grade 0 (normal) to grade IV (complete obstruction)[7].

Grade 0: Normal

Grade I: $1-25 \%$ stenosis

Grade II: $26-50 \%$ stenosis

Grade III: $51-75 \%$ stenosis

Grade IV: $76-100 \%$ stenosis

Statistical methods: Chi-square test was applied wherever required. A p -value $<0.05$ was statistically significant.

\section{Results}

Total number of heart specimens received in department of Pathology during four years was 272. Out of these 57 were autolysed and were excluded from the study.

All the deceased were grouped into specific age groups according to the age mentioned in the postmortem documents. In present study males $(73.02 \%)$ out numbered the female (26.98\%). Most of the specimens of heart were from age group 21-30 years (Table No.1).

Table No.-1: Sex distribution of postmortem cases.

\begin{tabular}{|c|c|c|c|}
\hline Age group in years & Males (\%) & Female (\%) & Total (\%) \\
\hline$<21$ & 12 & 8 & $20(9.30)$ \\
\hline $21-30$ & 44 & 22 & $66(30.69)$ \\
\hline $31-40$ & 29 & 16 & $45(20.93$ \\
\hline $41-50$ & 33 & 5 & $38(17.67)$ \\
\hline $51-60$ & 23 & 2 & $25(11.62)$ \\
\hline $61-70$ & 12 & 2 & $14(6.51)$ \\
\hline$>70$ & 4 & 3 & $7(3.5)$ \\
\hline & $157(73.02)$ & $58(26.98)$ & 215 \\
\hline
\end{tabular}

$\%=$ Percentage 


\section{Original Research Article}

Out of total 215 specimens of heart, 181(84.18\%) specimens showed presence of different grades of atherosclerotic lesions in both right and left coronary arteries each (figure 1). Thirty-four specimens did not show any atherosclerotic lesion in either of the coronary arteries.

Commonest prevalent atherosclerotic lesion in present study was of type I (32.59\%). Significant coronary artery disease (type IV to type VIII) in right and left coronary arteries was seen in 54 (29.83\%) and 64 specimens $(35.35 \%)$ respectively.

Type $\mathrm{V}$ was the most common significant atherosclerotic lesion in right coronary artery and type VII as most common significant atherosclerotic lesion in left coronary artery. Least common was type VI (3.86\%) in right and type VIII in left coronary artery $(2.76 \%)$ (Table no 2$)$.

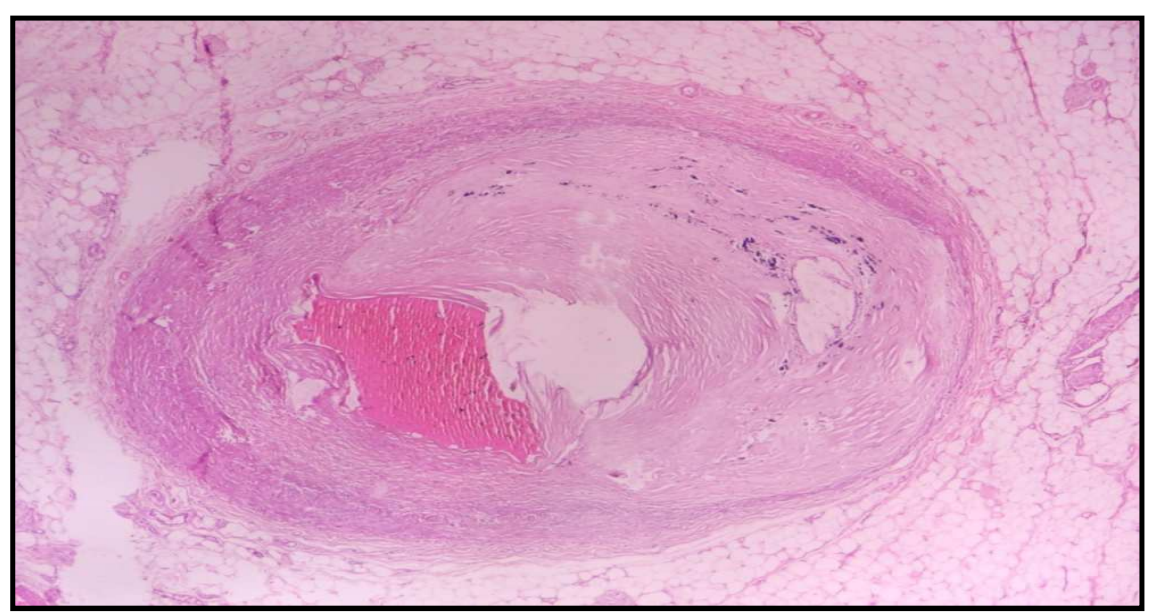

Figure-1: Left coronary artery with atherosclerotic plaque type VIII (H \& E, 4x).

Table No-2: Frequency distribution of atherosclerotic lesions in right and left coronary artery.

\begin{tabular}{|c|c|c|c|c|}
\hline Atherosclerosis type & $\begin{array}{c}\text { Right Coronary } \\
\text { Artery (Number) }\end{array}$ & $\begin{array}{c}\text { Right Coronary } \\
\text { Artery (\%) }\end{array}$ & $\begin{array}{c}\text { Left Coronary } \\
\text { Artery (Number) }\end{array}$ & $\begin{array}{c}\text { Left Coronary } \\
\text { Artery (\%) }\end{array}$ \\
\hline I & 58 & 32.04 & 59 & 32.59 \\
\hline II & 51 & 28.17 & 48 & 26.51 \\
\hline III & 18 & 9.94 & 10 & 5.52 \\
\hline IV & 11 & 6.07 & 13 & 7.18 \\
\hline V & 16 & 8.83 & 18 & 9.94 \\
\hline VI & 7 & 3.86 & 8 & 4.41 \\
\hline VII & 12 & 6.62 & 20 & 11.04 \\
\hline VIII & 8 & 4.41 & 5 & 2.76 \\
\hline $\begin{array}{c}\text { IV to VIII } \\
\text { Grade (significant } \\
\text { atherosclerosis grades) }\end{array}$ & 54 & 29.83 & 64 & 35.35 \\
\hline TOTAL & $\mathbf{1 8 1}$ & $\mathbf{8 4 . 1 8}$ & $\mathbf{1 8 1}$ & $\mathbf{8 4 . 1 8}$ \\
\hline
\end{tabular}

Significant CAD lesions were seen in 54 (25.11\%) and 64 (29.76\%) cases in right and left coronary arteries respectively and were statistically significantly higher among age group $>41$ years as compared to those with age $<41$ years $(p$ value $=0.000)$ in both right and left coronary arteries.

In this study the overall atherosclerotic lesions were significantly higher age groups $>41$ years as compared to $<41$ years ( $\mathrm{p}$ value $=0.000$ ) and also significant $\mathrm{CAD}$ lesions were statistically significant higher among age group $>41$ years as compared to those with age $<41$ years ( $\mathrm{p}$ value $=0.000$ ) in both right and left coronary arteries (Table III) 


\section{Original Research Article}

Table-III: Correlation of types of coronary atherosclerosis with age.

\begin{tabular}{|c|c|c|c|c|c|c|c|c|c|c|c|c|c|c|c|c|c|c|c|}
\hline \multirow{3}{*}{ 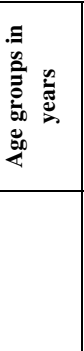 } & & \multicolumn{18}{|c|}{ Type of coronary artery atherosclerosis } \\
\hline & & \multirow{2}{*}{\multicolumn{2}{|c|}{$\mathbf{I}$}} & \multirow{2}{*}{\multicolumn{2}{|c|}{ II }} & \multicolumn{2}{|c|}{ III } & \multicolumn{2}{|c|}{ IV } & \multicolumn{2}{|c|}{$\mathbf{V}$} & \multicolumn{2}{|c|}{ VI } & \multicolumn{2}{|c|}{ VII } & \multirow{2}{*}{\multicolumn{2}{|c|}{ VIII }} & \multicolumn{2}{|c|}{$\begin{array}{c}\text { Total } \\
\text { significant } \\
\text { atherosclerotic } \\
\text { lesions }\end{array}$} \\
\hline & & & & & & $\mathbf{R}$ & $\mathbf{L}$ & $\mathbf{R}$ & $\mathbf{L}$ & $\mathbf{R}$ & $\mathbf{L}$ & $\mathbf{R}$ & $\mathbf{L}$ & $\mathbf{R}$ & $\mathbf{L}$ & & & $\mathbf{R}$ & $\mathbf{L}$ \\
\hline$<21$ & 20 & 5 & 7 & 6 & 4 & 0 & 1 & 0 & 0 & 0 & 0 & 0 & 0 & 0 & 0 & 0 & 0 & 0 & 0 \\
\hline $21-30$ & 66 & 27 & 20 & 16 & 18 & 7 & 5 & 1 & 3 & 2 & 3 & 0 & 0 & 1 & 1 & 0 & 0 & 4 & 7 \\
\hline $31-40$ & 45 & 13 & 15 & 12 & 12 & 2 & 2 & 2 & 2 & 3 & 2 & 1 & 0 & 2 & 1 & 2 & 2 & 10 & 7 \\
\hline $41-50$ & 38 & 6 & 8 & 6 & 7 & 4 & 1 & 4 & 5 & 5 & 4 & 3 & 3 & 2 & 5 & 2 & 2 & 16 & 19 \\
\hline $51-60$ & 25 & 3 & 2 & 7 & 5 & 2 & 1 & 2 & 2 & 4 & 6 & 3 & 3 & 4 & 6 & 1 & 0 & 14 & 17 \\
\hline $61-70$ & 14 & 3 & 7 & 3 & 1 & 2 & 0 & 1 & 1 & 2 & 2 & 0 & 0 & 1 & 5 & 0 & 0 & 4 & 8 \\
\hline$>70$ & 7 & 1 & 0 & 1 & 01 & 1 & 0 & 1 & 0 & 0 & 1 & 0 & 2 & 2 & 2 & 3 & 1 & 6 & 6 \\
\hline TOTAL & 215 & 58 & 59 & 51 & 48 & 18 & 10 & 11 & 13 & 16 & 18 & 7 & 8 & 12 & 20 & 8 & 5 & 54 & 64 \\
\hline$\%$ & & 26.97 & 27.44 & 23.72 & 22.32 & 8.37 & 4.65 & 5.11 & 6.04 & 7.44 & 8.37 & 3.25 & 3.72 & 5.58 & 9.30 & 3.72 & 2.32 & 25.11 & 29.76 \\
\hline
\end{tabular}

$\mathrm{R}=$ Right Coronary Artery

$\mathrm{L}=$ Left Coronary Artery

Different grades of coronary artery luminal narrowing were observed in total 74(34.41\%) and 69(32.09\%) cases in right and left side respectively out of total 215 specimens (figure 2). Grade I (12.55\%) was most common in right coronary artery and Grade III(15.81\%) was the most common among left coronary artery. Coronary artery luminal narrowing was statistically significantly higher among age group $>41$ years as compared to those with age $<41$ years $(p$ value $=0.000)$ in both right and left coronary arteries (Table no 4).

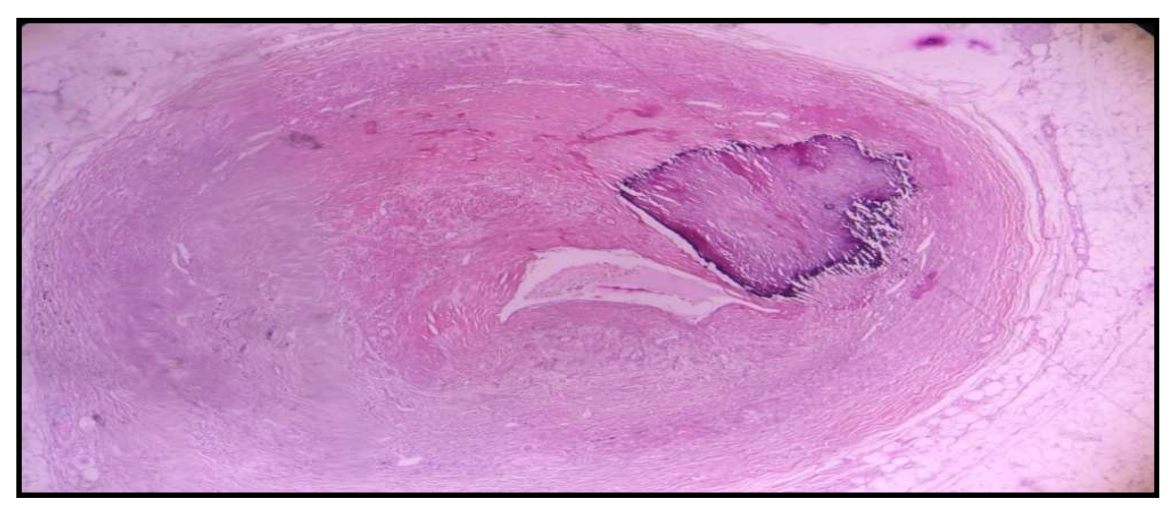

Figure-2: Coronary artery with $90 \%$ luminal obstruction (Grade IV) (H \& E, 4x)

Table-IV: Correlation of grading of coronary luminal narrowing with age.

\begin{tabular}{|c|c|c|c|c|c|c|c|c|c|c|c|}
\hline $\begin{array}{c}\text { Age } \\
\text { groups } \\
\text { in years }\end{array}$ & $\begin{array}{c}\text { Total } \\
\text { number } \\
\text { of cases }\end{array}$ & \multicolumn{2}{|c|}{ Grade I } & \multicolumn{2}{c|}{ Grade II } & \multicolumn{2}{c|}{ Grade III } & \multicolumn{2}{c|}{ Grade IV } & \multicolumn{2}{c|}{ Total } \\
\hline$<21$ & 20 & 1 & 0 & 0 & 0 & 0 & 0 & 0 & 0 & 1 & 0 \\
\hline $21-30$ & 66 & 5 & 5 & 2 & 1 & 0 & 1 & 1 & 2 & 8 & 9 \\
\hline $31-40$ & 45 & 3 & 2 & 2 & 2 & 5 & 4 & 2 & 1 & 12 & 9 \\
\hline $41-50$ & 38 & 7 & 1 & 3 & 3 & 9 & 11 & 1 & 3 & 20 & 18 \\
\hline $51-60$ & 25 & 4 & 2 & 4 & 3 & 6 & 8 & 4 & 5 & 18 & 18 \\
\hline $61-70$ & 14 & 4 & 0 & 1 & 1 & 2 & 7 & 1 & 1 & 8 & 9 \\
\hline$>70$ & 7 & 3 & 1 & 0 & 1 & 2 & 3 & 2 & 1 & 7 & 6 \\
\hline TOTAL & $\mathbf{2 1 5}$ & $\mathbf{2 7}$ & $\mathbf{1 1}$ & $\mathbf{1 2}$ & $\mathbf{1 1}$ & $\mathbf{2 4}$ & $\mathbf{3 4}$ & $\mathbf{1 1}$ & $\mathbf{1 3}$ & $\mathbf{7 4}$ & $\mathbf{6 9}$ \\
\hline$\%$ & & 12.55 & 5.11 & 5.58 & 5.11 & 11.16 & 15.81 & 5.11 & 6.04 & 34.41 & 32.09 \\
\hline
\end{tabular}




\section{Original Research Article}

$\mathrm{R}=$ Right Coronary Artery

$\mathrm{L}=$ Left Coronary Artery

Out of 215 specimens of heart, $41(19.06 \%)$ specimens showed different significant myocardial lesions, acute MI was seen in 2 case $(0.93 \%)$, chronic ischemic heart disease in 28 case $(13.02 \%)$ and cardiac hypertrophy in 11 cases $(5.11 \%)$ (figure $3 \& 4$ ). Out of these agegroup of 51-60 years showed maximum number of myocardial lesions (12/41) followed by age group 41-60years (10/41) (Table no 5).

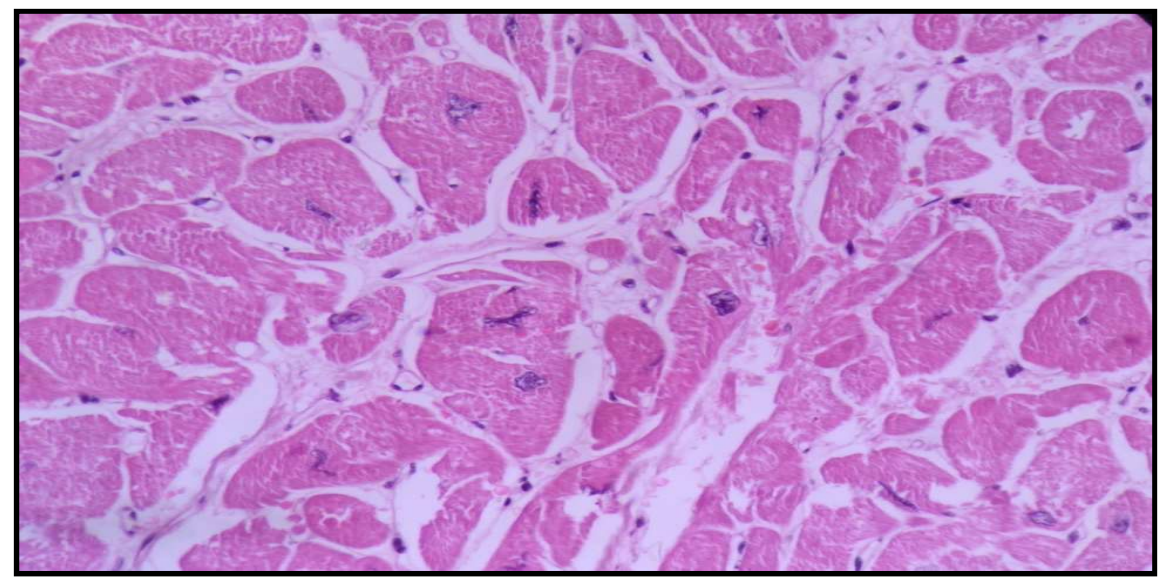

Figure-3: Section from the left ventricular wall showing hypertrophy(H \& E,40x)

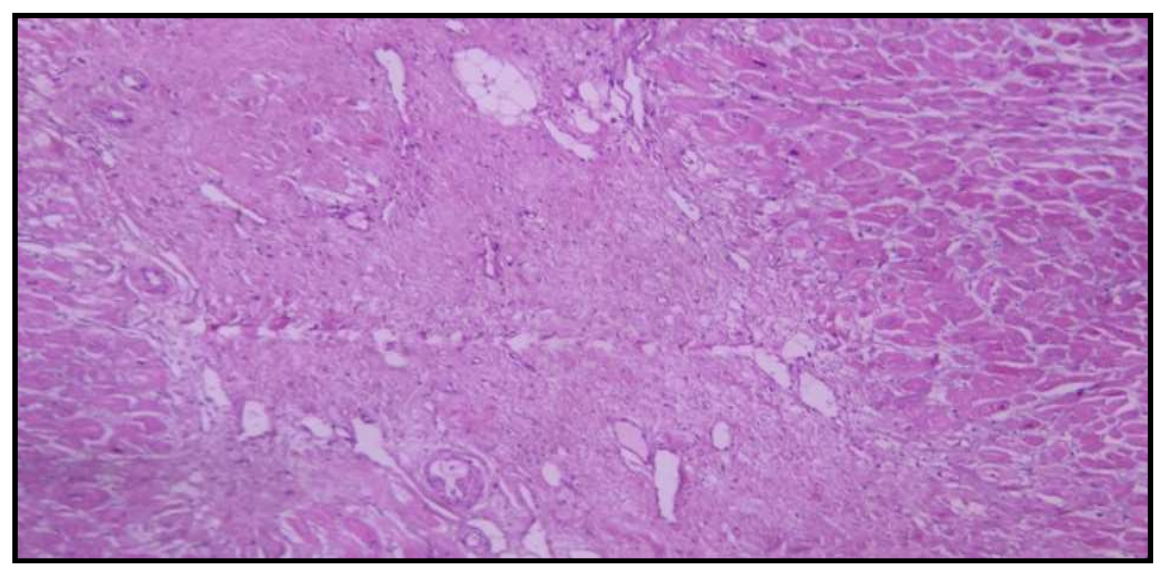

Figure-4: section from the left ventricle showing features of chronic ischemic heart disease. (H \& E, 10x)

Table-V: Correlation of significant cardiac lesions (Ischemic Heart Disease) with age

\begin{tabular}{|c|c|c|c|c|c|}
\hline $\begin{array}{c}\text { Age groups in } \\
\text { years }\end{array}$ & $\begin{array}{l}\text { Total number } \\
\text { of cases }\end{array}$ & $\begin{array}{c}\text { Acute } \\
\text { Myocardial } \\
\text { Infarction }\end{array}$ & $\begin{array}{c}\text { Chronic } \\
\text { ischemic heart } \\
\text { disease }\end{array}$ & $\begin{array}{l}\text { Hypertrophy of } \\
\text { ventricular wall }\end{array}$ & $\begin{array}{c}\text { Total number } \\
\text { (percentage) }\end{array}$ \\
\hline$<21$ & 20 & 0 & 0 & & 0 \\
\hline $21-30$ & 66 & & 2 & 1 & $3(1.39 \%)$ \\
\hline $31-40$ & 45 & & 4 & 1 & $5(2.32 \%)$ \\
\hline $41-50$ & 38 & 1 & 7 & 2 & $10(4.65 \%)$ \\
\hline $51-60$ & 25 & 1 & 8 & 3 & $12(5.58 \%)$ \\
\hline $61-70$ & 14 & & 4 & 4 & $8(3.72 \%)$ \\
\hline$>70$ & 7 & & 3 & & $3(1.39 \%)$ \\
\hline Total (\%) & 215 & $2(0.93)$ & $28(13.02)$ & $11(5.11)$ & 41(19.06) \\
\hline
\end{tabular}




\section{Original Research Article}

Table-VI: Correlation of significant cardiac lesions (Ischemic Heart Disease) with type of atherosclerosis

\begin{tabular}{|c|c|c|c|c|c|c|}
\hline $\begin{array}{c}\text { Coronary } \\
\text { atherosclerotic } \\
\text { grades }\end{array}$ & Number & $\begin{array}{c}\text { Acute } \\
\text { myocardial } \\
\text { infarction }\end{array}$ & $\begin{array}{c}\text { Chronic } \\
\text { ischemic } \\
\text { heart disease }\end{array}$ & $\begin{array}{c}\text { Hypertrophy of } \\
\text { ventricular wall }\end{array}$ & Total & $\mathbf{\%}$ \\
\hline I & 68 & & 4 & 1 & 5 & 7.35 \\
\hline II & 54 & & 2 & 1 & 3 & 5.55 \\
\hline III & 19 & & 2 & 3 & 5 & 26.31 \\
\hline IV & 14 & & 1 & 1 & 2 & 14.28 \\
\hline V & 20 & 1 & 3 & 0 & 4 & 20.00 \\
\hline VI & 9 & 1 & 1 & 1 & 3 & 33.33 \\
\hline VII & 21 & & 11 & 3 & 14 & 66.66 \\
\hline VIII & 8 & 1 & 5 & & 6 & 75 \\
\hline
\end{tabular}

Table-VII: Correlation of significant cardiac lesions (Ischemic Heart Disease) with grades of luminal narrowing.

\begin{tabular}{|c|c|c|c|c|c|c|}
\hline $\begin{array}{c}\text { Coronary luminal } \\
\text { narrowing grades }\end{array}$ & $\begin{array}{c}\text { Total } \\
\text { number }\end{array}$ & $\begin{array}{c}\text { Acute } \\
\text { Myocardial } \\
\text { Infarction }\end{array}$ & $\begin{array}{c}\text { Chronic } \\
\text { Ischemic } \\
\text { Heart Disease }\end{array}$ & $\begin{array}{c}\text { Hypertrophy o } \\
\text { ventricular wal }\end{array}$ & Total & $\%$ \\
\hline I & 27 & - & 1 & 3 & 4 & 14.81 \\
\hline II & 13 & - & 3 & 2 & 5 & 38.46 \\
\hline III & 35 & 2 & 10 & 4 & 16 & 45.71 \\
\hline IV & 15 & 1 & 8 & 1 & 10 & 66.66 \\
\hline
\end{tabular}

Maximum number of significant cardiac lesion were associated with atherosclerotic type VIII lesions (75\%) followed by type VII (66.66\%) and type VI(33.33\%) (Table 6). Maximum number of significant myocardial lesions were associated with grade IV(66.66\%) coronary luminal narrowing followed by grade III (45.71) and grade II(38.46). They were least associated with grade I coronary artery luminal narrowing (14.81\%) (Table No 7).

\section{Discussion}

Atherosclerosis is a disease of large and medium sized muscular arteries, characterized by inflammation of smooth muscle cells and formation of atherosclerotic plaques composed of necrotic cores; calcium deposits and an accumulation of modified lipids, endothelial cells, leukocytes, and foam cells [8-13]. Buildup of material and infiltrates leads to vascular remodeling, acute and chronic luminal obstruction, abnormalities of blood flow and diminished oxygen supply to target organs $[9,10,14]$. In human beings, atherosclerosis is the most common pathologic process leading to cardiovascular disease [14-16].

Coronary artery disease (CAD) is a leading cause of death of women and men worldwide. An estimated 17.5 million people died from this cause in 2005, representing $30 \%$ of all deaths in the world; of these, 7.6 million were caused by coronary heart disease [17]. Coronary artery disease due to atherosclerosis is an epidemic in India. The incidence of coronary artery disease has doubled during past three to four decades. It will soon emerge as the single largest diseaseaccounting for nearly one-third of all deaths in India. A total of nearly 6.4 crore cases of coronary vascular disease are likely in the year 2015 ; nearly $96 \%$ would be coronary heart disease cases. Deaths from this group of diseases are likely to amount to be a staggering 34 lakh. An estimated 1.3 million Indians diedfrom this in 2000. The projected death from coronary artery disease by 2015 is 2.95 million, of which $14 \%$ will be $<30$ years, $31 \%$ will be $<40$ years[2].

Ischemic heart disease (IHD) is defined as acute or chronic form of cardiac disability due to imbalance between supply and demand of oxygenated blood. In more than $90 \%$ cases the cause of myocardial ischemia is reduced blood flow due to coronary atherosclerosis. Thus, IHD is often termed coronary artery disease (CAD) or coronary heart disease (CHD)[18]. The autopsy study provides a means of understanding the basic process which sets a stage for clinically significant atherosclerotic cardiovascular disease. There is no valid method of sampling of living population. It was; therefore, considered that death suspected due to any reason, probably provide the best sample of the living population for studying atherosclerosis and their correlation with ischemic heart diseases. In this study total number of heart specimens received in department 
of Pathology during four years was 272. Out of these 57 $(20.95 \%)$ were autolysed and were excluded from the study. Porwal V et al[7] also observed 19.84\% (26 out of total 131) autolysed heart specimens in their study and $15.65 \%$ (18 out of total 115) by Garg Met al [1]. In the present study it was observed that 157 cases $(73.02 \%)$ were males and $58(26.98 \%)$ were females which are more or less similar to most of the studies done in past. Garg M et al [1] in their study observed $80.9 \%$ male and $19.01 \%$ female, Murthy et al [19] studied 150 cases out of which $123(82 \%)$ were males and 27(18\%) were females. Singh et al [20] studied 200 cases with $170(85 \%)$ males and $30(15 \%)$ females. Padmavati [21] and Tandon [22] found $66.5 \%$ males and $33.5 \%$ females. Similarly Bhargava et al [23] studied $74.8 \%$ males and $24.2 \%$ females in their study. The reasonbeing that as males are bread earners and females usually doing house hold work, which makes the males more vulnerable to accidents, violence and stress. Also males more indulge themselves in smoking; alcoholism etc.

All the deceased were grouped into specific age groups according to the age mentioned in the postmortem documents. In our study, most of the specimens of heart specimens were from age group 21-30 years. All the micro sections were examined microscopically for the presence of different types of atherosclerosis and myocardial infarction / fibrosis/hypertrophy. According to American Heart Association, typing of atherosclerotic plaques was done from type I to type VIII $[5,6]$.

Aging is associated with structural and functional changes of the vessel wall, which result indecreased vascular dispensability and elevated arterial stiffness $[17,24]$. As a consequence of arterial stiffness, systolic blood pressure increases, causing a rise in left ventricular workload and subsequent hypertrophy, and diastolic blood pressure decreases, leading to an impairedcoronary perfusion [24, 25].

In this study the overall atherosclerotic lesions (type I to type VIII) were significantly higher amongage groups $>41$ years as compared to $<41$ years and also significant atherosclerotic lesions (type IV to type VIII) were statistically significantly higher among age group $>41$ years as compared to those with age $<41$ years ( $p$ value $=0.000$ ) in both right and left coronary arteries. Dhruv et al [26], Garg M et al [1]also reported increased frequency of atherosclerosis from 3rd decade onwards. Stressful, sedentary lifestyle, lack of exercise and poor dietary habits are the important factors for early initiation and development of atherosclerosis in young generation.

\section{Original Research Article}

Age is a powerful risk factor for coronary heart disease. The development of atherosclerosis increases markedly with age up to an age of about 65 , regardless of sex and ethnic background [27, 28]. Major advances in medical, interventional and surgical therapy, together witheffective secondary prevention, has resulted inextended life expectancy and an improvement inthe quality of life of most patients with clinicalcoronary artery disease. Despite these achievements, the prevalence of coronary artery disease seems toremain high. However, the exact data on theprevalence of coronary atherosclerosis or clinicalcoronary artery disease are extremely diverse [29]. Overall incidence of atherosclerosis was foundto be $84.18 \%(181 / 215)$ in both the right and left coronary arteries our present study, however frequency given by Garg M et al [1]was (46\%), Yazdi (40\%) [30] and Golshahi et al (28.9\%) [31].

Significant atherosclerotic lesions (type IV to type VIII) appearedin seconddecade onwards and there after there is a gradual increase both in its severity and frequency from third decade onwards. Maximum incidence was in fourth decade $(88.9 \%)$ followed by in fifth decade.

Overall incidence of significant atherosclerotic lesions was $25.11 \%$ in right and $29.76 \%$ in left coronary artery. Earlier studies also in India by Wiget al[32] found significant atheroma in two-third of cases above the age of 20 years while Tandon [22] found atherosclerosis in second and thirddecade. Singh et al [20] found atherosclerosis atthe age of 17 years. Thereafter, there was steep rise in all the studies. Although we cannot explain the reason for sudden increaseafter the third decade but it deserves to attract enough attention. In present studyalso significant CAD lesions were statistically significantly higher among age group $>41$ years as compared to those with age $<41$ years (p value $=0.000$ ) in both right and left coronary arteries.

Commonest prevalent atherosclerotic lesion in present study was of type I (27.97\%).However, preatheroma (type III) type was the most common type, in study by Garg M et al (30.9\%) [1] and Porwal V et al (40.07\%) [7], Sudha et al [33], Virmaniet al [34] \& Staryet al [35] found ruptured plaque as most common type with the frequency $11 \%, 37.5 \% \& 33 \%$. However, Dhruv et al [26] showed more cases of atheroma (27.4\%) followed by preatheroma (23.8\%).). In our study, typeV (fibro-atheroma) $(8.37 \%)$ was the most common significant atherosclerotic lesion in right coronary artery and type VII (with calcification present) $(9.30 \%)$ as most common significant atherosclerotic lesion in left coronary artery. Least common was type VI (3.25\%) in right and type VIII in left coronary artery $(2.32 \%)$. 
Significant atherosclerotic lesions (type IV to type VIII) in right and left coronary arteries were seen in 54 $(25.11 \%)$ and 64 specimens $(29.76 \%)$ respectively. In the study by Porwal Vet al [7], the overall incidence of significant atherosclerosis was found to be $55.33 \%$, by Shirani et al[36]was (65\%) and by McGill et al[37] it was $(58 \%)$ in their studies.

Ischemic heart disease due to $\mathrm{CAD}$ is mainly caused by atherosclerosis. In general slowly developing coronary atherosclerosis of high grade (fibroatheroma) may not cause acute lesions but complications in atherosclerotic plaque in the form of superimposed coronary thrombosis due to plaque rupture or thrombosis may lead to acute attack. Those patients who survived attack showed changes of chronic myocardial ischemia in the form of focal or diffuse myocardial fibrosis, so small areas of fibrous scarring are found in elderly patients who have history of attacks of MI years back. Hearts from patients with chronic IHD are usually enlarged and heavy, due to left ventricular hypertrophy and dilation. Myocardial hypertrophy represents

\section{Original Research Article}

compensatory mechanism to meet the cardiac demand as hypoxia is produced by significant coronary atherosclerosis. In our study, $41(19.06 \%)$ specimens showed different types significant myocardial lesions, acute MI was seen in 2 case $(0.93 \%)$. In study by Garg $\mathrm{M}$ et al [1], acute MI was seen in 3 cases ( $3 \%)$, by Maru (6.5\%) [38] and however Bharti Jha et al [39]12.3\%, Porwal Vet al[7] 18.44\% and Shiladaria P et al [40] in $22.5 \%$ of cases.

Present study shows that maximum number of significant cardiac lesion were associated with atherosclerotic type VIII lesions followed by type VII and type VI correlating with findings of Garg Met al [1] who observed that Maximum cases of significant cardiac lesions were associated with advanced atherosclerotic lesions i.e.type VI \& type VII lesions.

In our study maximum cases of ischemic heart diseases were seen between $5^{\text {th }}-6^{\text {th }}$ decade of life. In study by Porwal Vet al [7], the maximum cases of ischemic heart diseases were seen between $4^{\text {th }}-5^{\text {th }}$ decade of life.

\section{Conclusions}

The study of human atherosclerotic lesion is an extremely difficult task in a living subject and an autopsy study is the best possible way to work on it. Our study aids valuable data to the literature regarding the morphology of atherosclerotic lesion and its relation to the significant cardiac lesion. Significant atherosclerotic lesions were seen in 54(25.11\%) and $64(29.76 \%)$ cases in right and left coronary arteries respectively and were statistically significant higher among age group $>41$ years as compared to those with age $<41$ years. The study also showed significant correlation between the higher grade of the coronary atherosclerotic lesions and the ischemic heart disease.

\section{What is new in this study?}

This study brings attention to the burden of the atherosclerosis in mewat region of Haryana. To the best of our knowledge no such study has been conducted in our institute, it also highlights a need of life style changes in general public and also calls for screening programmes and prevention and control measures against atherosclerosis from early age.

Funding: Nil, Conflict of interest: None initiated

Permission from IRB: Yes

Contribution of authors during study process and manuscript preparation:

\begin{tabular}{|c|c|c|c|c|c|c|c|}
\hline \multirow[t]{2}{*}{ Nature of work } & \multicolumn{7}{|c|}{ Authors } \\
\hline & 1 & 2 & 3 & 4 & 5 & 6 & 7 \\
\hline Concepts & $\nabla$ & & & & & & \\
\hline Design & $\nabla$ & & & & & & \\
\hline Definition of intellectual content & & $\nabla$ & $\nabla$ & & & & \\
\hline Literature search & $\nabla$ & $\nabla$ & & & & & \\
\hline Data acquisition & $\nabla$ & $\nabla$ & $\nabla$ & $\nabla$ & $\nabla$ & $\nabla$ & \\
\hline Data analysis & $\nabla$ & $\nabla$ & & & & & $\nabla$ \\
\hline Statistical analysis & & & & & & & $\nabla$ \\
\hline Manuscript preparation & $\nabla$ & $\nabla$ & & & & & \\
\hline Manuscript editing & & $\nabla$ & & & & & \\
\hline Manuscript review & $\nabla$ & $\nabla$ & $\nabla$ & & & & \\
\hline
\end{tabular}




\section{Original Research Article}

\section{References}

1. Garg M, Aggarwal A, Kataria S. Coronary Atherosclerosis and Myocardial Infarction. An autopsy study. J Indian Acad Forensic Med.2011;33:971-973.

2. Indrayan A. Forecasting vascular disease cases and associated mortality in India. NCMH Background Papers: Burden of Disease in India. National commission on macroeconomics and Health, Government of India; 2005.p.197-215.

3. Gaziano TA. Cardiovascular disease in the developing world and its cost-effective management. Circulation. 2005; 112(23): 3547-53. doi:10.1161/ CIRCULATIONAHA. 105.591792.

4. Beaglehole R, Reddy S, Leeder S. Poverty and human development. The global implications of cardiovascular disease. Circulation. 2007; 116: 1871-1873.

5. Bertomeu A, García-Vidal O, Farré X, Galobart A. Preclinical coronary atherosclerosis in a population with low incidence of myocardial infarction: cross sectional autopsy study. BMJ. 2003; 327:591- 2.

6. Stary HC. Natural History and Histological Classification of Atherosclerotic Lesions: An Update. Arterioscler Thromb Vasc Biol. 2000; 20; 11771178.

7. Porwal V, Khandelwal S, Jain D, Gupta S.Histological Classification of Atherosclerosis and Correlation with Ischemic Heart Disease: A Autopsy Based Study. Annals of Pathology and Laboratory Medicine. 2016; 3 (2):99-104.

8. Bavelaar FJ, Beynen AC. Atherosclerosis in parrots: a review. Vet Q. 2004;26:50-60.

9. Brunkwall J, Mattsson E, Bergqvist D. Dietinduced atherosclerosis in rabbits alters vascularprostacyclin release. Eicosanoids. 1992;5: 197-202.

10. Fricke C, Schmidt V, Cramer K. Characterization of atherosclerosis by histochemical and immunohistochemical methods in African grey parrots (Psittacus erithacus) and Amazon parrots(Amazona spp.). Avian Dis. 009;53:466-72.

11. Centers for Disease Control and Prevention CDC. Racial/ethnic and socioeconomic disparities inmultiple risk factors for heart disease and stroke. MMWR Morb Mortal Wkly Rep. 2005;54:113-7.
12. Galkina E, Ley K. Immune and inflammatory mechanisms of atherosclerosis. Annu Rev Immunol. 2009; 27:165-97.

13. Hansson GK, Libby P. The immune response in atherosclerosis: a doubleedgeds word. Nat Rev Immunol. 2006;6:508-19.

14. Silverman S. Diagnostic Imaging. In: Mader DR, editor. Reptile Medicine and Surgery. 2nd ed. St.Louis: Saunders Elsevier; 2006. p. 471489.

15. Willecke F, Yuan C, Oka K, Chan L, Hu Y, Barnhart S, et al. Effects of High Fat Feeding and Diabetes on Regression of Atherosclerosis Induced by LowDensityLipoprotein Receptor Gene Therapy in LDL Receptor Deficient Mice. PLoS One. 2015;10 (6): e0128996.

16. Smith SC, Smith EC, Taylor Jr RL. Susceptibility to spontaneous atherosclerosis in pigeons: anautosomal recessive trait.J. Heredity. 2001;92:439-42.

17. Bairey NCB, Merz BD, Johnson BL, Sharaf WISE. Hypoestrogenemia of hypothalamic origin and coronary artery disease in premenopausal women: a report from the NHLBIsponsored WISE study. J Am Coll Cardiol. 2003; 41:413-9.

18. Kumar V, Abbas A, Aster J. The Heart. Robbins And Cortans Pathological Basis Of Disease. 2015; 9th Ed: 523-578.

19. Murthy MSN, Dutta BN, Ramalingaswami V. Coronary atherosclerosis in North India (Delhi Area). J Pathol Bacteriol.1963;85:93-101.

20. Singh H, Oberoi SS, Gorea RK, Bal MS. Atherosclerosis in Coronaries in Malwa Region of Punjab. J Indian Acad Forensic Med. 2005; 27 (4): 32-5.

21. Padmavati S, Sandhu I. Incidence of coronary artery disease in Delhi from medico-legal autopsies. Indian Journal of Medical Research. 1969; 57:465-475.

22. Tandon OP, Aggarwal VC, Katiyar BC. Coronary and aortic atherosclerosis. Indian Heart J.1969; $5: 10$.

23. Bhargava MK, Bhargava SK. Coronary atherosclerosis in North Karnataka. Indian J Pathol Microbiol. 1975;18:65-77. 


\section{Original Research Article}

24. Chirinos JA, Segers P, Duprez DA, Brumback L, Bluemke DA, Zamani $P$, et al. Late systolic central hypertension as a predictor of incident heart failure: the Multiethnic Study of Atherosclerosis. J Am Heart Assoc. 2015;4 (3):e001335.

25. Bertomeu A, GarcíaVidal O, Farré X. Preclinical coronary atherosclerosis in a population with low incidence of myocardial infarction: cross sectional autopsy study. British Med J. 2003;327(7415):591-2.

26. Dhruva GA, Agravat AH, Sanghvi HK. Atherosclerosis of coronary arteries as predisposing factor in myocardial infarction: An autopsy study. Online J Health Allied Scs. 2012 11:1.

27. Stetter MD. Ultrasonography. In: Mader DR, editor. Reptile Medicine and Surgery. 2nd ed. St. Louis: Saunders Elsevier; 2006. p. 6656-74.

28. Pearson TA, Blair SN, Daniels SR, Eckel RH, Fair JM, Fortmann SP. AHA guidelines for primary prevention of cardiovascular disease and stroke: 2002 update: Consensus panel guide to comprehensive risk reduction for adult patients without coronary or other atherosclerotic vascular diseases. American Heart Association Science Advisory and Coordinating Committee. Circulation.2002;106:388-91.

29. Widimsky P, Andel M. Prevalence of coronary atherosclerosis in asymptomatic population. Eur Heart J. 2000;21:13-14.

30. Yazdi SAT, Rezaei A, Azari JB, Hejazi A, Shakeri MT, Shahri MK. Prevalence of Atherosclerotic Plaques in Autopsy Cases with Noncardiac Death. Iranian J Pathol. 2009;4(3):101-104.

31. Golshahi J, Rojabi P, Golshahi F. Frequency of atherosclerotic lesions in coronary arteries of autopsy specimens in Isfahan forensic medicine center. J Res Med. 2005;1(10):16-9.
32. Wig KL, Malhotra RP, Chitkara NL, Gupta SP. Prevalence of Coronary Atherosclerosis In Northern India. BMJ.1962;2:510-3.

33. Sudha ML, Sundaram S, Purushothaman KR, Kumar PS, Prathiba D. Coronary atherosclerosis in sudden cardiac death: An autopsy study. Indian J Pathol Microbiol. 2009;52(4):486-9.

34. Virmani R, Kolodgie FD, Burke AP, Farb A, Schwartz SM. Lessons from sudden coronary death - A comprehensive morphological classification scheme for atherosclerotic lesions. ArteriosclerThrombVasc Biol. 2000; 20:1262-75.

35. Stary HC, Chandler AB, Glagov S, Guyton JR, InsullW,Rosenfeld ME, Schaffer A, Schwartz CJ, Wagner WD, Wissler RW. A definition of initial, fatty streak, and intermediate lesions of atherosclerosis. ArteriosclerThromb. 1994;14:840-856.

36. Shirani J, Youseti, Roberts WC. Major cardiac findings at necropsy in 366 American octogenarians. Am J Cardiol. 1995:75,151-156.

37. Mcgill HC, Brown BW, Gorel et al. Grading stenosis in the right coronary artery. Circulation. 1968; 37: 460-468.

38. Maru M. Coronary atherosclerosis and myocardial infarction in autopsied patients in Gondar, Ethiopia. J R Soc Med.1989;82(7):399-40.

39. Bharti Jha et al. Incidence of coronary atherosclerosis in different coronary arteries and its relation with myocardial infarction: a randomized study in 300 autopsy heart in tertiary care hospital. International journal of Medical Science and Public Health. 2013; 2: 836-839.

40.Shiladeria $\mathrm{P}$ et al.Coronary atherosclerosis and myocardial infarction, an autopsy study. NJIRM. 2013; 4: 106-108.

\section{How to cite this article?}

Singh P, Satarkar R.N, Kalhan S, Hasija S, Bhawna, Sangwaiya A, Chawla S. Correlation of coronary artery atherosclerosis typing and luminal narrowing with ischemic myocardial lesions in post mortem heart specimens: a four year retrospective study.Trop J Path Micro 2018;4(3):248-257.doi:10. 17511/jopm.2018.i3.03 